\title{
Strategi Komunikasi Pemasaran Kementerian Pariwisata Indonesia dalam Pesona Indonesia melalui Youtube
}

\author{
Mardhiyah Azzahrani \\ Program Studi Ilmu komunikasi, Fakultas Komunikasi dan Bisnis Universitas Telkom
}

\begin{abstract}
ABSTRAK
Pariwisata di Indonesia terus dikelola dengan serius oleh pemerintah Indonesia guna meningkatkan dan mengembangkan obyek-obyek wisata yang ada di Indonesia dengan maksud dan tujuan tidak lain untuk meningkatkan jumlah kunjungan wisatawan baik dari wisatawan mancanegara ataupun nusantara. Pariwisata di indonesia sendiri di kelola oleh Kementerian Pariwisata Indonesia yang memiliki brandingWonderful Indonesia yang ditujukan bagi wisatawan mancanegara dan Pesona Indonesia yang di tujukan untuk wisatawan nusantara. Dimana dalam penelitian ini akan lebih lanjut dibahas mengenai strategi komunikasi pemasaran Kementerian Pariwisata Indonesia melalui Pesona Indonesia dalam Youtube, dimana Youtube merupakan salah satu media promosi yang dimiliki Kementerian Pariwisata Indonesia dan merupakan media yang efektif untuk digunakan. Penelitian ini menggunakan metode deskriptif kualitatif dan paradigma konstruktivis. Data-data dalam penelitian diperoleh melalui wawancara yang dilakukan secara offline. Dimana informan dalam penelitian ini berjumlah tiga orang yang merupakan bagian dari Tim Bidang Pengembangan Pemasaran Pariwisata Nusantara. Hasil penelitian yang didasarkan pada teori Public Relations dan karakteristik media sosial Youtube menunjukanbahwa strategi komunikasi pemasaran Kementerian Pariwisata Indonesia melalui Pesona Indonesia dalam Youtube menggunakan kampanye digital yang didukung dengan penggunaan endorse berupa artis ataupun vlogger guna meningkatkan ketertarikan khalayak baik menyaksikan video yang ada di Youtube ataupun melakukan perjalanan wisata.
\end{abstract}

Kata kunci: Komunikasi Pemasaran, Public Relations, Youtube, Media Baru, Pariwisata

\section{Marketing Communication Strategy Ministry of Tourism Indonesia in Pesona Indonesia on Youtube Platform}

\begin{abstract}
Indonesia's tourism has been managed recently by the goverenment to improve and develop many tourism attractions in Indonesia to increase the visitor number either from local visitor or foreign visitor. Tourism in Indonesia that managed by Kementrian Pariwisata Indonesia (Ministry of Indonesia Tourism) make a branding for it's tourism attractions as "Wonderful Indonesia" to the foreign visitor as its market target and "Pesona Indonesia" to the local visitor as its market target, in which of this paper would be researched to define the Marketing Communication Strategy of Ministry of Indonesia Tourism by making the "Pesona Indonesia" branding for the local visitor. The method of this research paper is Qualitative Description. All datas in this paper gather by Interviewing all 3 person from the Tourism Marketing and Development of Ministry of Indonesia Tourism. The result by using Public Relations theory and characteristics of social media Youtube showed that the Marketing Communication Strategy made by Ministry of Indonesia Tourism through the "Pesona Nusantara" as the branding on Youtube is using a digital campaign followed by endorsing some artist
\end{abstract}


or vlogger to increase the public awareness to watch the video of the campaign on Youtube or even visit the local tourism attractions instead.

Keyword: Marketing Communication, Public Relations, Youtube, New Media, Tourism

Korespondensi: Mardhiyah Azzahrani. Universitas Telkom. Jl. Telekomunikasi, Jl. Terusan Buah Batu No.01, Sukapura, Dayeuhkolot, Bandung, Jawa Barat 40257 Email: azzahranim@gmail.com

\section{PENDAHULUAN}

Dewasa ini, Indonesia sedang giat dalam pemasaran pariwisatanya, baik kepada wisatawan lokal maupun wisatawan mancanegara. Pemasaran yang giat tersebut dilakukan terkait dengan Peraturan Presiden RI No.69 Tahun 2015 tentang bebas visa kunjungan Indonesia, yang mengatur kebebasan visa kunjungan bagi wisatawan asing yang dilakukan bertujuan untuk meningkatkan hubungan Negara Republik Indonesia dengan negara lain, serta guna meningkatkan perekonomian nasional dan peningkatan jumlah kunjungan wisatawan. Pariwisata sendiri merupakan salah satu sumber pendapatan bagi suatu negara tak terkecuali Negara Indonesia yang didukung dengan kekaya dan keindahan alamnya serta kaya akan budaya yang dimiliki. Di Indonesia sendiri, pariwisata yang ada dikelola oleh Kementrian Pariwisata Indonesia, dimana dalam pengelolaan pariwisata ini, Kementrian Pariwisata Indonesia memiliki empat deputi yang memiliki bidangnya masing-masing, yaitu Deputi Bidang Pengembangan Destinasi dan Industri Pariwisata, Deputi Bidang Pengembangan Pemasaran Mancanegara, Deputi Bidang Pengembangan Pemasaran
Nusantara, serta Deputi Bidang

Pengembangan Kelembagaan

Kepariwisataan.

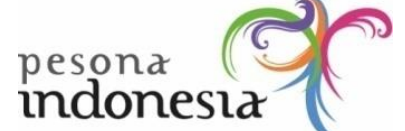

Gambar 1 Logo Pesona Indonesia Sumber: pesonaindonesia.travel (2016)

Kementerian Pariwisata Indonesia melakukan strategi komunikasi pemasarannya dengan mengelola branding yang bernama Pesona Indonesia yang dikelola olehBidang Pengembangan Pemasaran Nusantara yang menjadi strategi utama dalam menarik wisatawan khususnya wisatawan nusantara. Pesona Indonesia sendiri merupakan branding dari Kementrian Pariwisata Indonesia yang sudah ada sejak tahun 2014. Tujuan dibuatnya branding Pesona Indonesia adalah untuk memasarkan pariwisata yang dimiliki Indonesia dengan 10 destinasi pariwisata nusantara potensial yang diutamakan kepada wisatawan nusantara, serta dengan tujuan untuk meningkatkan kunjungan wisatawan nusantara untuk berwisata di negerinya sendiri, serta menyadarkan masyarakat Indonesia bahwa Indonesia memiliki Pesona yang tidak kalah 
dengan negara lain yang dapat mereka kunjungi.

Pesona Indonesia berbeda dengan Wonderful Indonesia, yang mana Wonderful Indonesia lebih diperuntukan bagi wisatawan Mancanegara yang tentunya juga memiliki destinasi pariwisata potensial mancanegara yang berbeda dengan nusantara. Dalam mengkomunikasikan branding Pesona Indonesia, Kementerian Pariwisata Indonesia menggunakan beberapa media, baik media konvensional maupun media baru, yang mana diantara media konvensional yang digunakan yaitu media cetak, media luar ruang, media elektronik. Media baru yang digunakan Kementerian Pariwisata Indonesia dalam mengkomunikasikan pemasaran pariwisata Indonesia terdiri dari berbagai media, diantaranya melalui situs website resmi Pesona Indonesia yang disertakan dengan $e$ mail, Youtube, Facebook, Twitter, dan Instagram. Penelitian ini memfokuskan pada strategikomunikasipemasaranyang digunakan oleh Kementerian Pariwisata Indonesia dalam mengkomunikasikan branding Pesona Indonesia yang khususnya dalam menggunakan media baruyaitudalambentuk media sosialberupa Youtube yang termasuk dalam kegiatan bauran komunikasi pemasaran Public Relations.

Media yang digunakan dalam mengkomunikasikan pemasaran Pesona Indonesia melalui akun Youtube resmi yang dimiliki Kementerian Pariwisata Indonesia, bernama Indonesia.Travel. Hingga 21 Oktober 2016, pukul 23.01 WIB, total dari keseluruhan yang tertulis di akun Youtube resmi ini sudah mendapat 26.975 subscribers dan 30.142.710 views.

Berdasarkan pemaparan pendahuluan tersebut, peneliti ingin mengetahui bagaimana strategi komunikasi pemasaran Kementerian Pariwisata Indonesia dalam Pesona Indonesia melalui Youtube, oleh karena itu Peneliti memilih paradigma konstruktivisme agar Peneliti mendapatkan pemahaman mengenai fakta-fakta bagaimana Kementerian Pariwisata Indonesia mengkomunikasikan brangding Pesona Indonesia kepada target audiens nya melalui media Youtube yang termasuk dalam kegiatan public relations mereka yang dapat memberikan pemahaman serta ketertarikan mengenai Pesona Indonesia oleh target audiens dari strategi komunikasi pemasran Kementerian Pariwisata Indonesia.

\section{Komunikasi}

Komunikasi berasal dari bahasa Latin communis yang memiliki arti sama, communico, communicatio atau communicare yang berarti "membuat sama." Kata lain yang mirip dengan komunikasi adalah komunitas yang juga menekankan pada kesamaan atau kebersamaan. Terdapat beberapa pendapat mengenai pengertian komunikasi menurut ahli (dalam Mulyana, 2000) seperti diantaranya menurut Tubbs dan 
Moss, komunikasi adalah "proses penciptaan makna antara dua orang (komunikator 1 dan komunikator 2) atau lebih, kemudian ada juga menurut Gerald R. Miller, "komunikasi terjadi ketika suatu sumber menyampaikan suatu pesan kepada penerima dengan niat yang disadari untuk mempengarhui perilaku penerima." Serta menurut Harold Lasswell,“(Cara yang baik untuk menggambarkan komunikasi adalah dengan menjawab pertanyaan-pertanyaan berikut) who says what in which channel to whom with what effect? atau siapa mengatakan apa dengan saluran apa kepada siapa dengan pengaruh bagaimana?"

\section{Komunikasi Pemasaran}

Komunikasi pemasaran merupakan perpaduan dari dua kajian, yaitu komunikasi dan pemasaran. Komunikasi pemasaran menurut Pickton dalam Prisgunanto (2014) adalah semua elemen-elemen promosi dari bauran pemasaran yang melibatkan proses komunikasi antara organisasi dengan target audiens nya melalui berbagai media yang berpengaruh kepada performa pemasaran. Kotler berpendapat, bahwa komunikasi pemasaran adalah cara melihat keseluruhan proses komunikasi tetapi berasal dari cara pandang si konsumen bukan produsen. Sedangkan Menurut Shimp yang juga ada di dalam Prisgunanto (2014) komunikasi pemasaran adalah proses pengembangan dan implementasi berbagai bentuk program komunikasi persuasif kepada pelanggan secara berkelanjutan.

Komunikasi pemasaran tidak terlepas dengan bauran komunikasi pemasaran atau yang bisa juga disebut dengan marketing communication mix (marcommix). Menurut Kotler dalam Soemanegara (2006) bauran komunikasi pemasaran digunakan agar komunikasi pemasaran dapat berlangsung efektif dan efisien dengan penggabungan dari model-model komunikasi yang ada dalam pemasaran, bauran komunikasi pemasaran diantaranya adalah:

\section{Advertising}

Merupakan bentuk komunikasi nonpersonal mengenai suatu organisasi, produk, servis atau ide yang dibayar oleh suatu sponsor. Iklan bisa dibilang sebagai salah satu media promosi yang paling banyak diketahui dan dibahas oleh orang, oleh sebab itu iklan merupakan salah satu media promosi yang cukup penting bagi perusahaan besar yang memiliki target konsumen dengan tujuan masyarakat luas yang dapat menggunakan media massa seperti televisi, radio, majalah, ataupun koran. Terdapat tiga jenis iklan, yaitu Iklan Nasional, Iklan Lokal serta Iklan Primer dan Selektif.

2. Sales promotion

Merupakan kegiatan pemasaran yang memberikan nilai tambah atau insentif pada tenaga penjualan, distributor, 
atau konsumen yang diharapkan dapat meningkatkan penjualan, misalnya seperti potongan harga atau undian berhadiah. Promosi penjualan secara umum dibedakan menjadi dua, yaitu promosi penjualan berorientasi kepada konsumen yang ditujukan bagi pengguna akhir dari suatu barang atau jasa yang mencakup pemberian kupon, sampel produk, potongan harga, undian berhadiah, kontes dan lain sebagainya. Sedangkan promosi penjualan yang berorientasi kepada perdagangan ditujukan kepada pihakpihak yang menjadi perantara pemasaran seperti pedagang pengecer, pedagang besar dan distributor dengan bentuk promosi berupa pemberian bantuan dana promosi, pengaturan atau penyesuaian harga jual produk, kompetisi penjualan, pameran dagang dan lain sebagainya.

\section{Public Relations}

Definisi Public Relations menurut Frank Jefkins dalam Prisgunanto (2014) adalah bentuk komunikasi yang terencana, baik komunikasi kedalam ataupun keluar organisasi, dengan maksud mencapai tujuan dari organisasi. Scott Cutlip dalam Syarifuddin (2016) mendefinisikan Public Relations sebagai usaha terencana untuk mempengaruhi pandangan melalui karakter yang baik serta tindakan yang bertanggung jawab, yang didasarkan atas komunikasi dua arah yang saling memuaskan. Berkaitan dengan hal tersebut, Scott M.Cutlip (1994) menjelaskan landasan acuan program kerja Public Relationsyang disebut dengan "empat langkah-langkah pokok" yaitu:

a) Fact Finding (Penemuan Fakta)

Pada tahap ini, ditetapkan suatu fakta dan informasi yang berkaitan dengan kepentingan organisasi. Penemuan fakta dilakukan dengan tujuan mengetahui apakah opini, sikap dan reaksi dari masyarakat menunjang atau menghambat organisasi tersebut.

b) Planning and Decision (Perencanaan dan Pengambilan Keputusan)

Tahap ini merupakan kelanjutan dari tahap penemuan fakta, dimana tahap perencanaan ini merupakan tahap yang penting, hal in dikarenakan perencanaan menghubungkan kegiatan komunikasi dengan kepentingan organisasi. Biasanya seorang pelaku humas merencanakan keputuan dengan memperhatikan faktor-faktor seperti psikologis, sosiologis, keadaan sosial, ekonomi politik yang merupakan pesan dari komunikator yang 
dirumuskan agar dapat mencapai tujuan.

c) Communication and Action (Komunikasi dan Pelaksanaan)

Tahap komunikasi terkait dengan perencanaan tentang bagiamana mengkomunikasikan dan apa yang dikomunikasikan guna menumbulkan kesan-kesan yang efektif untuk mempengaruhi pihakpihak yang menjadi target dari strategi Public Relationstersebut. Suatu program komunikasi menyangkut pilihan-pilihan terhadap saluran komunikasi yang akan digunakan dalam berkomunikasi dengan publik sasaran. Pemilihan media saluran komunikasi disesuaikan dengan ketersediaan media, biaya, keterampilan komunikasi, publik sasaran dan tujuan komunikasi. Selain itu diperlukan juga penetapan jenis pesan serta tema-tema apa yang harus ditonjolkan.

d) Evaluation (Evaluasi)

Setelah tahap komunikasi dilaksanakan, suatu organisasi tentu ingin mengetahui bagiamana pengaruh yang terjadi pada target audiens mereka. Pada tahap ini, praktisi humas mengadakan penilaian terhadap hasil dari kegiatan-kegaiatn yang telah mereka lakukan serta menilai keefektivitasan dari teknik-teknik manajemen dan komunikasi yang telah mereka gunakan.

4. Personal selling

Menurut Fandy Tjiptono dalam Soemanagara (2006) personal selling adalah kegiatan komunikasi langsung antara penjual dengan calon pembeli dan membentuk pemahaman pembeli terhadap produk atau jasa yang ditawarkan sehingga menimbulkan kemungkinan pembelian. Sedangkan menurut Buchari Alma dalam Soemanagara (2006) personal selling merupakan kegiatan yang melibatkan komunikasi interpersonal antara pembeli dan penjual untuk memenuhi kebutuhan pembeli untuk kepentingan kedua pihak.

5. Direct selling

Merupakan bentuk organisasi dalam berkomunikasi secara langsung dengan calon konsumen guna mendapatkan tanggapan atau tindakan pembelian. Pemasaran langsung bukan sekedar melakukan pengiriman surat (direct mail) ataupun mengirimkan katalog perusahaan saja, tetapi pemasaran langsung mencakup kegiatan seperti pengelolaan database, penjualan 
langsung, telemarketing, dan iklan tanggapan langsung. Instrumen penting dalam pemasaran langsung adalah iklan tanggapan langsung, yaitu iklan dimana suatu produk atau jasa yang dipromosikan melalui media massa meminta atau mendorong konsumen untuk menggunakan atau membeli produk atau jasa tersebut secara langsung kepada pembuatnya.

6. Event

Event didefinisikan sebagai suatu kegiatan yang diselenggarakan untuk memperingati hal-hal penting sepanjang hidup manusia baik secara individu atau kelompok yang terikat secara adat, budaya, tradisi dan agama yang diselenggarakan untuk tujuan tertentu serta melibatkan lingkungan masyarakat yang diselenggarakan pada waktu tertentu. Sedangkan event menurut Shone dan Parry dalam Noor (2013) adalah fenomena yang timbul dari acara-acara yang tidak rutin yang berbentuk hiburan, kebudayaan, pribadi atau organisasi yang tujuannya dibedakan dari aktivitas rutin pada kehidupan sehari-hari, dengan tujuan untuk mencerahkan, merayakan, menghibur atau menantang guna menambah pengalaman sekelompok orang.
7. Exhibition

Exhibiton dapat dikatakan sebagai salah satu bagian dari event, exhibition biasanya menampilkan beragam jenis produk perusahaan yang dihadiri oleh banyak pengunjung untuk membeli produk tersebut. Dapat dikatakan exhibition bersifat mempertemukan penyedia produk atau jasa dengan pembeli dalam satu tempat. Tujuan diadakannya exhibition adalah memperkenalkan produk atau jasa suatu organisasi kepada masyarkaat luas (Noor, 2013).

8. Word of mouth

Word of mouth atau yang dapat disingkat dengan sebutan WOM dapat menjadikan suatu berita menjadi menguntungkan atau mendatangkan masalah, karena WOM sendiri merupakan sesuatu hal yang dibicarakan banyak orang, dimana pembicaraan terjadi karena adanya kontroversi yang membedakan dengan hal-hal yang biasa dan normal dilihat orang (Khasali dalam Soemanagara, 2006). Sedangkan menurut Rosen dalam Soemanagara (2006), word of mouth merupakan salah satu cara menyebarkan desas-desus atau yang dapat disebut dengan "buzz”. 
Istilah media secara sederhana dapat dijelaskan sebagai alat komunikasi sebagaimana definisi yang selama ini diketahui khalayak (Laughey dalam Nasrullah, 2015). Hampir semua definisi memiliki kecenderungan yang sama mengenai kata "media", yaitu sarana yang disertai teknologinya. Berdasarkan teknologi pola penyebarannya, media dibagi menjadi dua, yaitu media lama atau media konvensional (old media) dan media baru (new media). Media lama bersifat dari satu ke banyak seperti media massa yang berbentuk televisi, radio, koran, majalah, dan laizzzzzn sebagainya. Sedangkan media baru akan lebih lanjut dibahas di dalam penelitian ini.

\section{New Media}

Dewdney (2006) mendefinisikan new media dengan pengembangan karakter yang terus berkembang, namun formula yang mendasar dari teknologi yang digabungkan dengan konsep dan konteks akan menjadi petunjuk yang menjadi definisi new media, dengan kata lain, media baru merupakan media yang berbasis teknologi dalam bidang komunikasi maupun informasi yang memiliki konsep dan konteks. Banyak ahli yang sulit mendefinisikan arti dari media baru sehingga muncul berbagai pendapat mengenai definisi dari media baru, seperti hal nya yang dikatakan oleh Richard Hunter (2002), media baru merupakan world without secrets yang berarti bahwa kehadiran media baru menjadikan informasi sebagai sesuatu hal yang mudah dicari dan terbuka. Media baru memiliki beberapa jenis, yaitu media online dan media sosial.

\section{Media Online}

Pengertian

media online adalahsebagai media massa yang disajikan secara online dalam bentuk website, yang merupakan media massa generasi ketiga setelah media cetak dan media elektronik (Romli, 2016). Menurut Ashadi Siregar (2003) media online adalah sebutan umum untuk media telekomunikasi yang berbasis komputer dan internet, bentuk dari media online tersebut dapat berupa portal, website, jurnalistik online, radio online, televisi online, surat online dan lain sebagainya.

\section{Media Sosial}

Media sosial yang didefinisikan oleh Meike dan Young dalam Nasrullah (2015) adalah sebagai konvergensi antara komunikasi personal dalam arti saling berbagi di antara individu dan media publik untuk berbagi kepada siapa saja tanpa ada kekhususan individu. Sedangkan menurut Shirky dalam Nasrullah (2015) media sosial dan perangkat lunak sosial merupakan alat untuk meningkatkan kemampuan pengguna untuk berbagi, bekerja sama, di antara pengguna dan melakukan tindakan secara kolektif yang semuanya berada di luar kerangka institusional maupun organisasi.

\section{Youtube}

Youtube merupakan suatu situs yang memungkinkan miliaran orang menemukan, 
menonton dan berbagi video asli yang dibuat.Youtube dibangun oleh tiga orang, yang mana dua dari mereka, yaitu Chad Hurley dan Steve Chen lah yang paling terkait dengan pembangunan Youtube, seorang pendiri lainnya, yaitu Jawed Karim tidak terlalu aktif dalam perusahaan ini seperti kedua pendiri lainnya (Woog, 2009). Di dalam Youtube terdapat juga fasilitas bagi pengunjung situs Youtube untuk saling berinteraksi seperti subscribe, like/dislike, views dan comment, yang mana fasilitas interaksi tersebut dapat mempengaruhi eksistensi dari video yang ada di Youtube tersebut.

\section{Strategi}

Strategi sendiri berasal dari bahasa Yunani, "stratos" yang berarti militer dan "ag" yang artinya memimpin. Menurut Effendy dalam Prisgunanto (2014), strategi adalah perencanaan dan manajemen untuk mencapai suatu tujuan, untuk mencapai tujuan tersebut strategi digunakan tidak hanya sebagai peta yang menunjukan arah, tetapi juga menunjukan taktik operasionalnya. Strategi dalam bidang bisnis yang didefinisikan oleh Chandler dalam Prisgunanto (2014) merupakan penetapan tujuan dasar jangka panjang dan sasaran perushaan dan penerapan serangkaian tindakan serta alokasi sumber daya yang penting untuk melaksanakan sasaran tersebut.Strategi dalam komunikasi pemasaran menggambarkan pesan yang akan dibagi dengan target dari perusahaan (audience) melalui komunikasi pemasaran yang optimum dan dengan cara yang khusus dipersiapkan oleh perusahaan. Jadi, dalam suatu komunikasi pemasaran dibutuhkan strategi yang tepat sasaran agar visi dan misi perusahaan dapat tercapai.

\section{METODE PENELITIAN}

Penelitian ini menggunakan metode penelitian deskriptif kualitatif, yang mana dalam penelitian komunikasi, kualitatif biasanya dimaksudkan untuk mengemukakan gambaran atau pemahaman mengenai, bagaimana dan mengapa suatu gejala atau realitas komunikasi terjadi. Sedangkanmetode deskriptif adalah mempelajari masalah-masalah dalam masyarakat, serta tatacara yang berlaku dalam masyarakat serta situasi-situasi tertentu, termasuk tentang kegiatan-kegiatan, sikap, pandangan serta proses-proses yang sedang berlangsung dan pengaruh-pengaruh dari suatu fenomena (Nazir dalam Permana, 2015).

\section{HASIL DAN PEMBAHASAN}

Pada bagian ini, peneliti akan memaparkan pembahasan dari analisa hasil penelitian yang telah didapatkan. Hal ini bertujuan untuk memaparkan hasil yang akurat yang didasarkan pada data yang peneliti peroleh melalui wawancara dan observasi. 


\section{Penemuan Fakta}

Dalam tahap penemuan fakta atau informasi yang berkaitan dengan suatu orginasasi atau perusahaan, dilakukan untuk mengetahui bagaimana opini atau sikap dari publik organisasi tersebut. Apakah opini yang ada bersifat positif yang mendukung organisasi, ataukah sebaliknya yang menghambat organisasi atau perusahaan tersebut. Mengumpulkan segala bentuk data yang dibutuhkan oleh perusahaan untuk menjalankan komunikasi dengan publik juga termasuk dalam kegiatan penemuan fakta.

Kegiatan yang telah dilakukan Tim dari Kementerian Pariwisata Indonesia dalam pengumpulan fakta telah sesuai dengan apa yang dirumuskan oleh Scott M.Cutlipdalam Lena (2014) mengenai empat tahap penelitian penemuan fakta, yaitu:

a. Penelitian mengenai situasi yang sedang terjadi, khususnya mengetahui apa yang dipikirkan orang dan mengapa.

b. Penelitian mengenai prinsip-prinsip dasar humas yang sedang dilaksanakan.

c. Penelitian mengenai hasil dari opini, reaksi atau sikap dari target audiens

d. Mengadakan evaluasi bagaimana orang memberikan reaksi atau respon terhadap strategi yang akan dilakukan.
Poin a berhubungan dengan bagaimana Tim Public RelationsKementerian Pariwisata ini mengetahui bagaimana opini atau situasi publik yang ada saat ini, dimana opini publik yang ada saat ini adalah belum begitu tertarik untuk mengunjungi destinasi-destinasi yang ada di Indonesia karena terbentur dengan biaya perjalanan yang mahal.

Dalam menjalankan prinsip-prinsip dasar humas sesuai dengan poin $b$, Tim humas Kementerian Pariwisata Indonesia harus memperhatikan hal utama dalam kegiatan komunikasi pemasran yang mereka lakukan, yaitu mengetahui siapa target dari strategi yang akan mereka jalankan ini. Dimana target dari publik mereka adalah wisatawan nusantara denganusia 20-34 tahun yang merupakan usia potensial aktif yang dapat melakukan perjalanan wisata. Dengan mengetahui siapa target dari kegiatan strategi mereka maka Tim PR Kementerian Pariwisata Indonesia akan melakukan prinsipprinsip humas yang sewajarnya, yang tentunya mengutamakan kejujuran pesan yang akan disampaikan serta mengelola hubungan baik dengan target audiens mereka.

Sehubungan dengan hasil opini yang ada yang berkaitan dengan poin c. Kemudian Tim melakukan identifikasi terhadap publiknya mengenai bagaimana pesan yang diinginkan oleh publiknya agar dapat melakukan strategi yang dapat diterima baik oleh masyarkat. Identifikasi yang dilakukan Kementerian Pariwisata Indonesia ini berbentuk riset 
digital. Dari hasil identifikasi pesan seperti apa yang diinginkan oleh publiknya, ditemukan oleh Kementerian Pariwisata Indonesia bahwa keinginan pesan komunikasi pemasaran dari publiknya adalah dengan membuat konten komunikasi pemasaran melalui video seperti yang ada di Youtube saat ini.Kemudian dari poin terakhir, yaitu poin d. Dalam proses penemuan fakta juga diperlukan suatu tolak ukur yang dapat dijadikan acuan sebagai bahan evaluasi dari startegi yang akan dilakukan, apakah strategi tersebut berhasil atau tidak. Sehingga Kementerian Pariwisata Indonesia menetapkan tolak ukur keberhasilan dari strategi komunikasi pemasaran mereka yang menggunakan Youtube ini dengan melihat dari jumlah subscribe, views, like dan share yang didapatkan, apakah meningkat atau tetap.

\section{Perencanaan dan Pengambilan Keputusan}

Perencanaan adalah tahap yang cukup penting dalam menetapkan strategi apa yang akan dilakukan, karena berhubungan dengan kegiatan komunikasi perusahaan yang merupakan kegiatan terpenting dalam suatu perusahaan. Tahap perencanaan merupakan tahap lanjutan dari tahap penemuan fakta. Dalam hal ini, perencanaan butuh memperhatikan beberapa faktor seperti diantaranya faktor psikologis, sosiologis, sosial, ekonomi dan politik. Serta keputusan dari apa yang telah direncanakan merupakan salah satu cara untuk mencapai tujuan strategi yang dibuat.

Menurut Cutlip (1994)terdapat bebrapa langkah yang dapat dilakukan oleh praktisi PR, seperti hal nya yang telah dilakukan oleh Tim PR Kementerian Pariwisata, diantaranya yaitu kegiatan berikut:

a. Merumuskan tujuan yang harus dicapai dari suatu pesan yang disampaikan.

b. Mengolah data yang diperoleh dari tahap penemuan fakta. (Menganalisis informasi yang diperoleh serta merumuskannya sesuai dengan program kerja yang ada)

c. Merumuskan bagaimana pesan disebarkan, bagaimana teknik komunikasinya.

Berdasarkan kegiatan yang telah dilakukan, Kementerian Pariwisata merumuskan tujuan dari strategi yang mereka buat dengan tujuan men-sosialisasikan branding Pesona Indonesia agar banyak wisatawan nusantara yang tertarik melakukan perjalanan wisata di Indonesia. Selain itu Tujuan menggunakan Youtube adalah agar komunikasi yang disampaikan dapat cepat tersebar luas serta publik mereka dapat melihat dan menyadari keindahan Indonesia melalui video-video di Youtube Indonesia.Travel tersebut, serta terdapat alasan tersendiri Kementerian Pariwisata 
Indonesia memilih Youtube sebagai media komunikasi, hal itu dikarenakan Kementerian Pariwisata Indonesia sedang mengarahkan pariwisata ke arah digital, yang mana Youtube dianggap sebagai media yang efektif, karena pesan dapat tersebar lebih cepat, lebih mudah, lebih murah serta penyebaran pesan luas, terutama didukung oleh banyaknya anak muda yang sedang banyak mengakses Youtube pada saat ini, konten Youtube yang berbentuk audio dan visual serta dapat diberikan deskripsi teks pada video sehingga dianggap memiliki konten yang lengkap dan efektif.

Kemudian, Tim juga mengolah data yang telah diperoleh dari penemuan fakta pada hasil riset yang telah dilakukan sebelumnya, dimana publik menginginkan bentuk pesan berupa video seperti yang ada di dalam Youtube, sehingga dapat ditemukannya alasan mengapa perlu dilakukan strategi komunikasi pemasaran dalam branding Pesona Indonesia ini yang juga menggunakan Youtube, yaitu bila publik menyaksikan video di Youtube Indonesia.Travel dan tertarik untuk melakukan perjalanan wisata, hal tersebut dapat meningkatkan kesejahteraan masyarakat Indonesia lainnya dari segi pariwisata, terutama jika terdapat masyarakat Indonesia yang melakukan perjalanan wisata ke Indonesia, mereka ikut berpartisipasi dalam menambah pendapatan masyarakat Indonesia yang ada di destinasi yang dikunjungi mereka tersebut. Baik dari segi penginapan, pedagang makanan, pedagang oleh-oleh dan lainnya.

Berdasarkan alasan yang didapat dari pengolahan data pada riset yang telah dilakukan, hal tersebut dapat membantu Tim dari Kementerian Pariwisata untuk menentukan dan merumuskan bagaimana pesan atau teknik komunikasi yang akan disebarkan dari branding Pesona Indonesi melalui Youtube yaitu dengan merencanakan strategi kampanye digital yang mengandalkan Youtube dengan menggunakan endorse yang merupakan artisatau vlogger yang cukup berpengaruh.

\section{Komunikasi dan Action}

Menurut Cutlip (1994), tahap komunikasi ini tidak terlepas dari apa yang telah direncanakan dari tahap sebelumnya. Tahap ini merupakan tahap pelaksanaan dari perencanaan yang sudah di tetapkan dengan tujuan pesan dapat tersampaikan secara efektif dan mempengaruhi pihak yang menjadi target audiens nya. Suatu program komunikasi terkait dengan pilihan saluran atau media komunikasi apa yang dipilih untuk menyampaikan pesan komunikasi yang dipengaruhi oleh biaya, publik, ketersediaan media, serta keterampilan komunikasi. Selain media komunikasi, diperlukan juga menentukan jenis pesan dan tema pesan apa yang harus ditonjolkan saat menyampaikan komunikasi agar efektif. 
Berkaitan dengan hal tersebut, Timyang telah merencanakan dan mengambil keputusan strategi apa yang akan dilakukan, mulai melaksanakan pembuatan video yang memperlihatkan keragaman wisata yang ada di Indonesia dan melaksanakan pembuatan konten video kampanye digital yang menggunakan endorse seperti Pevita Pearce, Arief Muhammad, Salsabila Adriani, serta vlogger-vlogger yang cukup berpengaruh. Dimana video tersebut akan diunggah di Youtube dengan biaya pembuatan videovideo yang ada di dalam Youtube tersebut berasal dari dana APBN Kementerian Pariwisata dengan penyesuaian konten seperti apa yang akan dibuat.

Kemudian dari strategi kampanye digital tersebut, isi pesan yang ditonjolkan pada video yang dibuat menekankan pada bentuk video yang pesannya dalam dan mampu memancing emosi positif publik mereka, agar dapat mempengaruhi audiens melakukan perjalanan wisata di Indonesia. Pembuatan konten atau isi pesan dari video yang ada di Youtube Indonesia.Travel sendiri, bekerja sama dengan pembuat video professional (production house) dalam mengeksekusi video yang akan dibuat.

Dalam menyebarkan atau mengkomunikasikan video yang ada di Youtube tidak berdiri sendiri begitu saja, melainkan, menggunakan juga media sosial atau media online lainnya yang dimiliki Kementerian Pariwisata Indonesia khususnya dalam bidang pariwisata nusantara, yaitu diantaranya Twitter, Facebook serta Instagram yang digunakan untuk membagi cuplikan video dari apa yang ada di Youtube. Serta terdapat media online berupa website yang terkoneksi langsung dengan Youtube Indonesia.Travel. Selain menggunakan media baru yang dimiliki oleh Kementerian Pariwisata, audiens dari Youtube Indonesia.Travel yang sudah menonton video-video yang ada di Youtube Indonesia.Travel juga ikut menyebar luaskan video yang ada.

\section{Evaluasi}

Setelah proses komunikasi dari strategi dilaksanakan, maka suatu perusahaan atau organisasi perlu mengetahui dampak atau pengaruh serta hasil yang terjadi pada publiknya. Pada tahap ini, praktisi PR melakukan penilaian terhadap hasil dari program atau strategi yang telah dikerjakan. Menurut Kendall dalam Lena (2014) evaluasi dapat dilakukan melalui tujuh kegiatan untuk mengetahui apakah kegiatan humas tersebut berhasil atau tidak, yaitu:

a. Pencapaian sasaran, sejauh mana tujuan yang ditetapkan tercapai.

b. Pengukuran perbaikan hambatan

c. Pengukuran hasil, bentuk evaluasi

d. Efisiensi biaya, mengukur suatu program dengan menghitung nilai uang yang dihasilkan dengan uang yang dikeluarkan. 
e. Efek yang tak terencana, hasil like dan share yang dilakukan oleh audiens dari suatu kegiatan humas yang dari Youtube Indonesa.Travel. Dimana bentuk tidak terencana sesuai tujuan dari keberhasilan evaluasi ini dapat dikatakan awal. sudah berhasil karena audiens dari Youtube

f. Harapan-harapan atau inovasi ke masa selanjutnya.

Terkait dengan poin-poin di atas, pada poin pertama mengenai pencapaian tujuan, strategi Kementerian Pariwisata Indonesia ini yang didasarkan pada data yang dimiliki, tujuan strategi Kementerian Pariwisata ini sudah tercapai, meskipun Tim merasa masih dibutuhkan peningkatan lagi dari tujuan utama yang ada agar dapat melebihi dari target yang ditetapkan.

Kemudian pengukuran yang dilakukan dalam perbaikan hambatan yang ada, tidak terlalu banyak yang dilakukan. Hal ini dikarenakan pada kenyataan di lapangan tidak terjadi banyak hambatan selain hambatan yang menjadi opini publik yang ada sebelumnya, yaitu mengenai sulitnya mengajak wisatawan nusantara untuk melakukan perjalanan di Indonesia. Untuk selebihnya, hambatan yang ada berbentuk kesalah pahaman dengan pihak luar ketika sedang bekerja sama. Sehingga perbaikan hambatan yang dilakukan tidak terlalu dikhusus-kan karena hambatan yang ada dianggap tidak telalu krusial.

Pengukuran hasil evaluasi ditetapkan berdasarkan tolak ukur yang sudah ada, yaitu melalui peningkatan jumlah views, subscribe, Indonesia.Travel sudah mengalami peningkatan, bahkan hingga melakukan perjalanan wisata. Dari segi efisiensi biaya yang dilakukan, dapat pula kita ketahui dari bagian kegiatan komunikasi, dimana pembuatan konten komunikasi berupa video di Youtube semuanya disesuaikan dengan dana yang ada. Sehingga dapat dikatakan biaya yang digunakan cukup efisien dan tidak berlebihan.

Berdasarkan wawancara juga ditemukan efek tidak terencana dari strategi komunikasi pemasaran ini. Efek tak terencana yang ada bersifat positif. Bentuk dari efek tidak terencana itu adalah banyaknya masyarakat Indonesia yang membuat video. Bentuk keberlanjutan atau inovasi yang akan dilakukan oleh Kementerian Pariwisata Indonesa dalam mengelola atau membuat video-video Pesona Indonesia ini yaitu Tim akan melanjutkan strategi yang ada dalam hal penggunaan endorse dalam kampanye digital di Youtube, serta membuat video yang sedikit berbeda dengan video-video sebelumnya, yang akan menampilkan kuliner-kuliner yang ada di Indonesia, kebudayaan yang beraneka ragam, serta menggunakan latar musik lain yang bukan hanya theme song Pesona Indonesia saja seperti yang sudah-sudah.

\section{Video Category}


Kategori yang ada pada Youtube terdiri dari 14 kategori, yaitu kendaraan, komedi, hiburan, film dan animasi, alat dan permainan, how to\& DIY, music, berita dan politik, masyarakat dan blog, hewan peliharaan dan binatang, olahraga, perjalanan dan tempat, konten tidak tersedia serta konten terhapus. Berkaitan dengan kategori tersebut, konten Youtube dari Kementerian Pariwisata tergolong pada kategori perjalanan dan tempat dengan menggolongkan kembali kategori dengan fokus pada lima kategori video, yaitu nature, culture, sensory, modern dan adventure yang mana dari kategorikategori tersebut kembali di kelompokkan berdasarkan 10 destinasi prioritas yang ada.

\section{Video Length}

Biasanya konten video di Youtube merupakan video dengan durasi yang pendek dengan rata-rata durasi paling lama adalah 10 menit sampai 15 menit. Kemudian Youtube membuat inovasinya pada maret 2006 sehingga video yang diunggah dapat lebih dari 15 menit lamanya. Kementerian Pariwisata Indonesia sendiri tidak menentukan berapa lama durasi yang harus dibuat pada suatu video. Karena video yang dibuat disesuaikan dengan keperluan dari konten yang akan dibuat. Tetapi rata-rata yang sering dibuat oleh Kementerian Pariwisata sendiri berdurasi 30 detik hingga 5 menit.

\section{File Size dan Bit Rate}

Video yang dapat diunggah ke Youtube tidak boleh lebih dari 128GB. Youtube menyarankan ukuran video yang diunggah di atas dari 144p, yaitu 240p, 360p, 480p, 720p, 1080p, 1440p, 2160p agar memiliki kualitas gambar yang baik saat ditayangkan. Kementerian Pariwisata Indonesia sendiri tidak memiliki ketetapan khusus mengenai ukuran video yang akan diunggah ke Youtube, hanya saja tetap memperhatikan batas maksimal ukuran yang dapat diunggah. Serta Kementerian Pariwisata menyediakan pilihan kepada audiens nya mengenai ukuran kualitas gambar yang dimulai dari $144 p$ hingga 1080p agar audiens mereka dapat menyaksikan video sesuai dengan keinginannya.

\section{Data Added}

Mengunggah video ke Youtube sangat dipengaruhi oleh tanggal penambahan video yang ada dalam hal popularitasnya. Data yang dapat diunggah ke Youtube dapat berbentuk format video .MOV, .MPEG4, .AVI, .WMV, .MPEGPS, .FLV, 3GPP, WebM. Kementerian Pariwisata Indonesia tidak pernah menjadwalkan kapan sebuah video harus diunggah ke laman Youtube. Meskipun terdapat beberapa video-video yang baru diunggah, video-video yang telah lama diunggah juga tetap banyak diminati oleh audiens dari Youtube Indonesia.Travel ini. Tim dari media online nusantara biasanya menggunakan format video berbentuk .MOV, 
mesikipun terkadang ada juga dalam bentuk format .AVI atau .MPEG4 untuk mengunggah video ke Youtube.

\section{Views and Ratings}

Youtube selalu berkaitan dengan popularitas video yang dipengaruhi oleh jumlah views, subscribe, like dan share yang dilakukan oleh audiens dari suatu Youtube tersebut. Pengguna Youtube baik pemilik akun ataupun audiens dapat melihat berapa banyak orang yang melihat, menyukai ataupun tidak menyukai suatu video yang ada di dalam Youtube. Tim media online nusantara yang mengelola Youtube memiliki mesin pencatat tersendiri untuk mencatat jumlah views, subscribe, like serta share yang dilakukan oleh audiens mereka. Dari data yang telah didapat jumlah views, subscribe, like dan share dari laman Youtube Indonesia.Travel telah mencapai target meskipun harus terus ditingkatkan.

\section{SIMPULAN}

Strategi komunikasi pemasaran Kementerian Pariwisata Indonesia dalam men-sosialisasikan branding Pesona Indonesia yang ditujukan bagi wisatawan nusantara sesuai dengan bauran komunikasi pemasaran Public Relationsyang didasarkan pada empat langkah pokok Public Relations dari Scott M.Cutlip, yaitu penemuan fakta, perencanaan dan pengambilan keputusan, komunikasi dan action, serta evaluasi.
Penemuan fakta yang ada berupa opini dari wisatan nusantara yang masih belum mau melakukan perjalanan wisata karena biaya perjalanan di Indonesia tidak sedikit dibanding dengan perjalanan wisata ke negara tetangga terdekat. Perencanaan dan pengambilan keputusan dari penemuan fakta yang ada, akhirnya Tim Public Relationsmemutuskan merencanakan strategi komunikasi pemasaran yaitu berupa kampanye digital menggunakan endorse yang menandalkan Youtube sebagai media efektif mereka. Komunikasi dan action yang telah mereka lakukan saat ini dengan membuat video-video Youtube dengan konten video yang bertemakan 10 destinasi prioritas yang ada saat ini, dengan menggunakan endorse. Evaluasi dari hasil strategi Kementerian Pariwisata ini ditemukan bahwa tujuan mereka telah tercapai dengan bentuk keberhasilan meningkatnya jumlah views, like, subscribe dan share serta telah tercapainya target jumlah wisatawan nusantara yang melakukan perjalanan. Alasan pemilihan media Youtube yang digunakan sebagai salah satu media komunikasi pemasaran Kementerian Pariwisata Indonesia dikarenakan Youtube dianggap menjadi media yang paling efektif saat ini yang didasarkan pada kecepatan, kemudahan, kebebasan biaya, serta keluasan dalam penyampaian pesan yang berbentuk video dengan konten audio dan visual, serta didukung oleh banyak nya anak muda yang 
menggunakan Youtube saat ini. Dimana ke efektifan Youtube Indonesia.Travel ini sesuai dengan karakter media sosial Youtube yang didasarkan oleh Cheng, Dale, dan Liu (2007)(video category, video length, file size and bit rate, data added, views and ratings). Video category, terdapat lima kategori video di dalam Youtube Indonesia.Travel, yaitu nature, culture, sensory, modern dan adventure.Video length, durasi pada videovideo di Youtube Indonesia.Travel tidak memiliki durasi yang tetap, tetapi biasanya berdurasi 30 detik hingga 5 menit. File size and bit rate, sehubung dengan tidak tetapnya durasi yang ada, maka ukuran file video yang diunggah ke Youtube tidak tentu selama masih sesuai dengan yang ditetapkan Youtube dengan menyediakan kualitas video mulai dari 144p hingga 1080p. Data added, video yang diunggah ke Youtube milik Kementerian Pariwisata Indonesia biasanya berbentuk format .MOV dan tidak ada waktu tetap untuk mengunggah video ke Youtube. Views and ratings, pencatatan views, like, subscribe dan share dilakukan menggunakan mesin pencatat yang dimiliki Tim media online nusantara dan terlihat peningkatannya dari hari ke hari.

\section{DAFTAR PUSTAKA}

Cutlip, S.M.,Center,A.H. \& Broom, G.M. 1994. Effective Public Relations. Edisi keenam. New Jersey: Prentice Hall.

Dewdney, Andrew, Peter Ride. 2006. The New Media Handbook. USA: Taylor \& Francis Group
Hunter, Richard. 2002. World Without Secrets: Business, Crime, and Privacy in the Age of Ubiquitous Computing. New York : John Wiley \& Sons,Inc

Lena, Satlita. 2014. Manajemen Kehumasan di Perguruan Tinggi. (Sumber: http: //staff.uny.ac.id/sites/default/files/MA NAJEMEN\%20\%20\%20KEHUMASA N\%20\%20DI\%20PERGURUAN\%20T INGGI_1.pdf)

Morissan. 2014. Periklanan-Komunikasi Pemasaran Terpadu. Jakarta: Prenada Media Group

Mulyana, Deddy. 2000. Ilmu Komunikasi Suatu Pengantar. Bandung: PT.Remaja Rosdakarya

Nasrullah, Rulli. 2015. Media Sosial: Prosedur, Tren dan Etika. Bandung: Simbiosa Rekatama Media

Noor, Any. 2013. Manajemen Event. Bandung : Alfabeta

Permana, TrisnaAdidanLilisPuspitasari. 2015. Strategi Pemasaran Public Relations MD Entertainment padaPemasaran Film HabibiedanAinun. (Sumber: http: //jurnal.unpad.ac.id/jkk/article/view/73 91)

Prisgunanto, Ilham. 2014. Komunikasi Pemasaran Era Digital. Jakarta: CV.Prisani Cendekia

Republik Indonesia. 2015. PeraturanPresiden No.69 Tahun 2015 TentangBebas Visa Kunjungan. Lembar Negara RI Tahun 2015 No.133.Sekretariat Negara. Jakarta

Romli, Asep Syamsul M. 2016. Jurnalistik Online: Panduan Mengelola Media Online. Bandung: Nuansa Cendekia

Siregar, Ashadi. 2003. Politik Editorial Media Indonesia: Analisis Tajuk Rencana. Jakarta: Pustaka LP3ES

Soemanagara. 2006. Strategic Marketing Communication (Konsep Strategis dan Terapan). Bandung: Alfabeta

Syarifuddin, Gassing dan Suryanto. 2016. Public Relations. Yogyakarta: Andi Offset

Woog, Adam. 2009. A Great Idea: Youtube. Chicago: Norwood House Press 
Xu Cheng, Cameron Dale dan Jiangchuan

Liu.2007.Understanding the

Characteristics of Internet Short Video

Sharing: YouTube as a Case Study.

(Sumber: http:

//www.cs.sfu.ca/ jcliu/Papers/Understa

ndingCharacteristics.pdf) 